\title{
Effect of Treatment With a Mixture of Amino Acids at Different Levels on Some Biochemical Parameters and Wool, Carcass Characterizes in the Arabi Lambs Breed
}

\author{
Waleed Y. Kassim*, Falah A. AL-Asadi, Basim S. Mohsen \\ Department of Animal Production, College of Agriculture, University of Basrah, Iraq.
}

\begin{abstract}
A total of eighteen healthy lambs, divided randomly into three groups (six animals for each group) as follows: 1) control group, 2) T1 treated a mixed amino acid at a dose $10 \mathrm{~g} / \mathrm{head}$ orally, 3) $\mathrm{T} 2$ treated a mixture amino acid at a dose $20 \mathrm{~g} / \mathrm{head}$ orally, to investigate the effect of treatment with a mixture of amino acids on some biochemical parameters (albumin, cholesterol, glucose, Fe, Zn, TSH and thyroid hormone), wool growth (crude weight, clean weight and fiber length) and carcass trails (weights of the hot carcass, shoulders, legs, ribs, the fat tail, lion, heart, liver, lungs and kidney) in Arabi lambs. The results showed significant $(\mathrm{P}<0.05)$ differences among treated groups in some biochemical parameters such as albumin, cholesterol glucose, TSH and thyroid hormone. T2 group was higher in those parameters especially after 90 days of treatment compared with the other groups. No significant differences were presented between groups in the concentrations of $\mathrm{Fe}$ and $\mathrm{Zn}$. Also, the results showed increased significantly $(\mathrm{P}<0.05)$ in wool and carcass characterizes when lams treated with $20 \mathrm{~g} / \mathrm{head}$ of mixture amino acid compared with other groups, in spite of, there were no significant differences between groups in some cuts such as the weights of lion, heart, liver, lungs and kidney.
\end{abstract}

Keywords | Amino acids, Biochemical parameters, Wool growth, Carcass characterizes, Arabi lambs.

Received | November 24, 2018; Accepted | December 22, 2018; Published | March 09, 2019

*Correspondence | Waleed Y Kassim, Department of Animal Production, College of Agriculture, University of Basrah, Iraq; Email: hassan.nima@uobasrah.edu. iq

Citation | Kassim WY, Al-Asadi FA, Mohsen BS (2019). Effect of treatment with a mixture of amino acids at different levels on some biochemical parameters and wool, carcass characterizes in the arabi lambs breed. Adv. Anim. Vet. Sci. 7(5): 383-388.

DOI | http://dx.doi.org/10.17582/journal.aavs/2019/7.5.383.388

ISSN (Online) | 2307-8316; ISSN (Print) | 2309-3331

Copyright $\odot 2019$ Kassim et al. This is an open access article distributed under the Creative Commons Attribution License, which permits unrestricted use, distribution, and reproduction in any medium, provided the original work is properly cited.

\section{INTRODUCTION}

$\mathrm{A}$ 11 animals need amino acids and most of those animals fed on low quality forages with unavailable protein or rearing under low grazing conditions. On the other hand, most commercial diets are poor in essential amino acids. Sheep in Iraq depend on grazing as nutritional system and that pasture is very variations in nutritional values through the year and it is classified as a low quality food. Additionally, the protein, which digests in the small intestine may not provide enough of amino acids for the metabolic processes because of there are many pathways led to decline the amount of amino acids, which comes from the analysis of protein in the gut, 1) A source of energy for growth and metabolism processes of micro-organisms in rumen. 2) Most of the amino acids are converting to organic acid, ammonia and carbon dioxide. (Hoover and Miller, 1991;
Islam et al., 2009).

Although, the rumen micro-organism provide amino acids to animals by fermentation the protein in the digestive tract, the amount and composition of amino acids, which absorption from small intestine depend on both quality and the amount of protein intake from diets. According to many studies the amino acids in the diet do not provide enough amounts to improve wool growth because of a part of amino acids go to other physiological operations such as growth body mass, udder, urine and milk production. In ruminants free amino acids rapidly degraded in the digestive tract, so supplementation the amino acids to the diet may be affect on elevation the amino acids which arrive to small intestinal (Velle et al., 1997).

The quantity and quality of wool are affected by many fac 
Table 1: The percentage (\%) of amino acid in a mixture.

$\begin{array}{llllll}\text { AA }^{*} & \text { Percentage } & \text { AA } & \text { Percentage } & \text { AA } & \text { Percentage } \\ \text { Alanine } & 4 & \text { Isoleucine } & 4 & \text { Serine } & 6 \\ \text { Arginine } & 5 & \text { Leucine } & 5 & \text { Threonine } & 4 \\ \text { Aspartic acid } & 5 & \text { Lysine } & 7 & \text { Tryptophan } & 5 \\ \text { Cysteine/Cysteine } & 7 & \text { Methionine } & 11 & \text { Tyrosine } & 4 \\ \text { Glutamine } & 5 & \text { Phenylalanine } & 4 & \text { Valine } & 4 \\ \text { Histidine } & 5 & \text { Proline } & 7 & \text { Glycine } & 8\end{array}$

"Distributed by Iovate Health Sciences Company - U.S.A.

tors such as nutrition, age, sex season environment condition etc. (Holman and Malau. Aduli, 2012). The nutrition influence through amount of energy and crude protein in the diet, which it is available for wool follicle growth, however, the mass of wool growth depended on the number of follicles and the rate growth fiber (Reis and Suhlu, 1994). So, to improve the wool growth required increase amount and composition of amino acids Reis and Schinckel (1963) reported that wool growth is affected by the proportions of different amino acids absorbed from the small intestine. The characterizes of wool such as crude and clean wool and fiber length are very important for quality and value of wool (Edriss et al., 2007). The crude wool means the wool yield with tarnishes, while, the clean wool means the wool yield without tarnishes like as wax, dust and vegetable matter (Thornberry and Atkins, 1984). The staple length is an index for fiber growth while the fiber length is inducted to growth rate.

Many factors could be affected and limited the characterizes of carcasses and growth of animals and the quantity and quality of the meat especially the balance between energy and protein in diet (Haddad et al., 2001). Yurtman et al. (2002) found improvement in growth performance when they used two levels of crude protein and two levels of methionine.

For across the problem of the low nutrition value and because of there is no data available which showing the relationship between treatment of a mixture amino acids and some physiological and production trails such as changes in biochemical parameters and wool, carcass characterizes in the Arabi lamb breed, for the reason described above, the objective of this study was to presented the influence of treatment with a mixture of amino acid at different levels on thus trails in the Arabi lambs breed.

\section{MATERIALS AND METHODS}

This study was carried out in the animal field of College of Agriculture- Basrah University from February to June 2018 to investigate the effect of treatment with a mixture of amino acids (Table 1) at different levels on some biochem- ical parameters and wool, carcass trails in Arabi lambs. A total of eighteen healthy lambs, six months old and $21.3 \mathrm{~kg}$ of body weight were divided randomly into three groups (six animals for each group) as follows: 1) control group, 2) T1 treated a mixed amino acid at a dose $10 \mathrm{~g} /$ head orally, 3 ) T2 treated a mixture amino acid at a dose $20 \mathrm{~g} / \mathrm{head}$ orally. A mixture amino acids were given at three times weekly for three months. All animals fedad libitum on the same diet (Table 2), pasture forage, clean water and the block of the minerals were available during all the day. Animals were weighted weekly to alter the amount of diets according to their body weight.

Table 2: The ingredients of compositions of the diet

\begin{tabular}{ll}
\hline Chemical composition & Ingredient \%* \\
\hline Barley & 50 \\
\hline Wheat bran & 35 \\
\hline Yellow corn & 10 \\
\hline Soybean meal & 4 \\
\hline $\begin{array}{l}\text { Vitamins and mineral premix } \\
\text { Chemical compositions, \% of DM }\end{array}$ \\
$\begin{array}{l}\text { Dry matter } \\
\text { Crude protein }\end{array}$ \\
$\begin{array}{l}\text { Crude fiber } \\
\text { Ash }\end{array}$ \\
$\begin{array}{l}\text { *The diet formed according to NRC (2010) to meet nutrient } \\
\text { requirements. }\end{array}$ \\
*The diet was given based on 2\% of body weight.
\end{tabular}

Ten $\mathrm{ml}$ of blood was collected from all animals from the jugular vein and putted in plastic tube without anticoagulants before treatment and at 30,60, 90 days of the experiment. Blood samples were separated by centrifugation at $3000 \mathrm{rpm}$ for 15 minutes. All serum samples were frozen under $-20^{\circ} \mathrm{C}$ until analysis time.

Albumin Cholesterol, Fe and $\mathrm{Zn}$ concentrations were determined by using a chemical kit of the France Biolabo company. Glucose concentration was measured by a chemical kit of the England Plamatec company. TSH (Thyroid stimulating hormone) and thyroid hormone concentrations were determined by using a procedure associated 
Table 3: Effect of treatment with a mixture of amino acids at different levels on some biochemical parameters in the Arabi lambs breed (Means \pm S.E.)

\begin{tabular}{llllll}
$\begin{array}{l}\text { Parameters } \\
\text { /Groups }\end{array}$ & $\begin{array}{l}\text { Albumin } \\
\mathbf{g} / \mathbf{1 0 0} \mathbf{~ m l}\end{array}$ & $\begin{array}{l}\text { cholesterol } \\
\mathbf{g} / \mathbf{1 0 0} \mathbf{~ m l}\end{array}$ & $\begin{array}{l}\text { Glucose } \\
\mathbf{m g} / \mathbf{m l}\end{array}$ & $\begin{array}{l}\mathbf{F e} \\
\mathbf{\mu g} / \mathbf{1 0 0} \mathbf{~ m l}\end{array}$ & $\begin{array}{l}\mathbf{Z n} \\
\boldsymbol{\mu g} / \mathbf{1 0 0} \mathbf{~ m l}\end{array}$ \\
\hline $\begin{array}{l}\text { Before Treatment } \\
\text { control }\end{array}$ & $4.96 \pm 0.21$ & $104.5 \pm 7.14$ & $35.5 \pm 5.12$ & $106.4 \pm 11.1$ & $0.88 \pm 0.01$ \\
\hline T1 & $4.87 \pm 0.21$ & $132.1 \pm 7.31$ & $36.6 \pm 7.56$ & $113.5 \pm 10.8$ & $0.99 \pm 0.05$ \\
T2 & $5.11 \pm 0.24$ & $137.7 \pm 7.14$ & $39.5 \pm 5.67$ & $113.8 \pm 12.1$ & $0.80 \pm 0.02$ \\
\hline After 30 days of treatment & & & & & \\
control & $4.67 \pm 0.21$ & $112.3 \pm 9.14$ & $66.5 \pm 9.12 \mathrm{~b}$ & $124.4 \pm 9.9$ & $0.51 \pm 0.04$ \\
\hline T1 & $4.83 \pm 0.90$ & $133.5 \pm 8.31$ & $67.8 \pm 10.9 \mathrm{~b}$ & $129.5 \pm 1.91$ & $0.49 \pm 0.02$ \\
\hline T2 & $5.06 \pm 0.09$ & $99.5 \pm 6.14$ & $75.5 \pm 9.11 \mathrm{a}$ & $128.8 \pm 13.2$ & $0.48 \pm 0.03$ \\
\hline After 60 days of treatment & & & & & \\
\hline control & $4.90 \pm 0.11 \mathrm{~b}$ & $114.2 \pm 6.90$ & $50.8 \pm 12.9 \mathrm{~b}$ & $127.4 \pm 10.23$ & $0.65 \pm 0.04$ \\
\hline T1 & $4.21 \pm 0.81 \mathrm{~b}$ & $115.6 \pm 7.89$ & $99.8 \pm 10.56 \mathrm{a}$ & 126.99 .76 & $0.63 \pm 0.05$ \\
\hline T2 & $5.67 \pm 0.44 \mathrm{a}$ & $126.7 \pm 5.55$ & $88.4 \pm 9.67 \mathrm{a}$ & 121.910 .12 & $0.62 \pm 0.04$ \\
\hline After 90 days of treatment & & & & & \\
\hline control & $4.85 \pm 0.21 \mathrm{~b}$ & $174.2 \pm 4.56 \mathrm{a}$ & $66.7 \pm 9.23 \mathrm{~b}$ & $115.6 \pm 10.11$ & $0.55 \pm 0.04$ \\
\hline T1 & $4.81 \pm 0.13 \mathrm{~b}$ & $145.6 \pm 8.99 \mathrm{~b}$ & $90.5 \pm 10.98 \mathrm{a}$ & $118.7 \pm 12.12$ & $0.54 \pm 0.02$ \\
\hline T2 & $5.33 \pm 0.33 \mathrm{a}$ & $156.7 \pm 6.66 \mathrm{ab}$ & $88.4 \pm 11.12 \mathrm{a}$ & $100.4 \pm 10.76$ & $0.56 \pm 0.03$ \\
\hline D2 & & & &
\end{tabular}

Different small letters within column means a significant difference $(\mathrm{P}<0.05)$ between treatment groups.

with the kit of Monobind Inc - USA Company.

Samples of wool were taken from all animals before the beginning and after 90 days of the experiment from the left shoulder in an area that placed in the midway between the belly and top lines by marking approximately $10 \mathrm{~cm}^{2}$ (Taherpour et al., 2012) and stored in nylon sacks. Those samples were transported to the laboratory to determine the trails of wool. Weights of curd wool and clean wool and fiber length were measured according to (Taherpour et al., 2012).

After the end of experiment three animals from each group were fasted for ten hours weighted and then slaughtered to determine immediately the trails of the carcass including, the weights of the hot carcass, shoulder, legs, ribs, the fat tail, lion, heart, liver, lungs and kidney thighs. Those pieces were measured by using a scale (weighted from 1 to $30 \mathrm{~kg}$ ). The obtained data were analyzed statistically using the SPSS program (2013). Statistically significant differences were determined at the $\mathrm{P}<0.05$ level of significance.

\section{RESULTS AND DISCUSSION}

Table (3) obtained treatment with a mixture of amino acids at different levels on some biochemical parameters in the Arabi lambs breed. No significant $(\mathrm{P}<0.05)$ difference in the concentration albumin, cholesterol, glucose, Fe and $\mathrm{Zn}$ between groups before treatment. The concentration of albumin increased significantly $(\mathrm{P}<0.05)$ in the blood of lamb after 60 and 90 of treatment with $20 \mathrm{~g} /$ head of mixture amino acid compared with other groups. As well known, albumin considers the major protein in blood, so, certainly the increase in the absorption of amino acids causes more protein synthesis (Egan and Macrae, 1979). The concentration of cholesterol was decreased significantly $(\mathrm{P}<0.05)$ in $\mathrm{T} 1$ and $\mathrm{T} 2$ animals after 90 of treatment compared with control group, owing due to the increase in metabolic processes in younger animals and those animals needs a lipid as a sources of energy, so, naturally cholesterol will decrease in blood to meet this requirement. Glucose concentration was increased significantly $(\mathrm{P}<0.05)$ in $\mathrm{T} 1$ and T2 animals after 60 and 90 of treatment compared to control group. In one of metabolic stages some of amino acids such as threonine converting to glucose and it have a role in the gluconeogenesis analysis through the dehydrates pathway (Egan and Macrae, 1979), or due to the higher metabolism as a result increase in thyroid hormone level secretion (Grodsky, 1979). These results agree with the results of (Abdel-Ghani et al., 2011) when he used to protected protein on male lambs. No significant $(\mathrm{P}<0.05)$ difference in the concentration $\mathrm{Fe}$ and $\mathrm{Zn}$ between groups in all of experiment periods.

Effect of treatment with a mixture of amino acids at different levels on concentrations of TSH and thyroid hormones was observed in Figures 1 and 2. TSH hormone was at the same levels in all groups before treatment, while declining significantly $(\mathrm{P}<0.05)$ after 30 days of treatment and 
then increase significantly $(\mathrm{P}<0.05)$ after 60 and 90 days of treatment in $\mathrm{T} 1$ and $\mathrm{T} 2$ in comparison to control group. Serum thyroid hormone concentration revealed a significant $(\mathrm{P}<0.05)$ increased in T1 and T2 animals after 60 and 90 days of treatment compared with control group, The reason of a thyroid hormone increase may due to one of amino acids, especially tyrosine, which is playing a role in the synthesis of thyroxin and tyriiodothronine hormones in the thyroid gland (Ana-Maria et al., 2009).

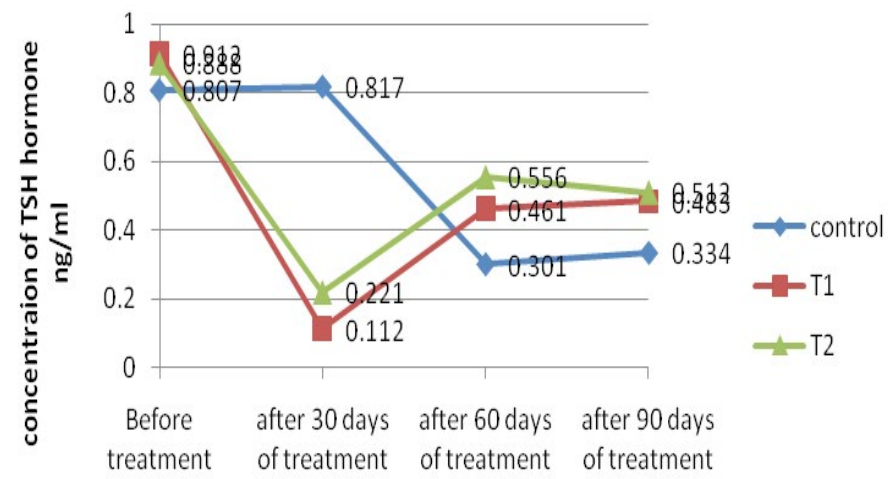

period

Figure 1: Effect of treatment with a mixture of amino acids at different levels on concentration of TSH hormone in the Arabi lambs breed.

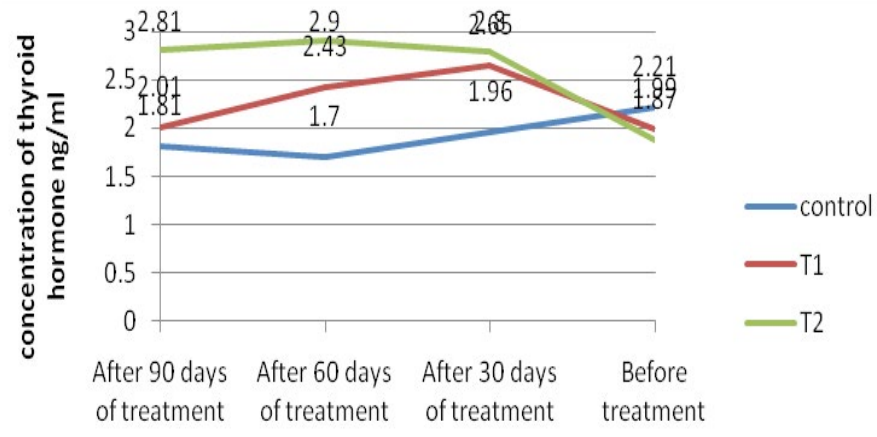

Period

Figure 2: Effect of treatment with a mixture of amino acids at different levels on concentration of thyroid hormone in the Arabi lambs breed.

Wool characterizes such as crude weight, clean wool and fiber length were significant $(\mathrm{P}<0.05)$ increase in T2 animals after 90 days of treatment compared with T2 and control groups (Table 4), this may be explained by the treatment with amino acids and improve the nutrition of animals have direct influence on wool growth and fiber length (Ries and Panaretto, 2001; Reis and Sahls, 1994). Black and Reis, (1979) suggested that amino acids helps the follicle to increase the rate of mitosis in the follicle bulb which led to increase the number of cells and increase the size of fiber cortical cells. This will reflect positively on the fleece weight and follicle density (Williams and Win- ston, 1987). Additionally, wool growth affected by the endocrine system hormones such as thyroid hormone (Khan et al., 2012), So, from our data that shows in Figure (2) there is an increase in the thyroid hormone in T1 and T2 groups may cause elevation in wool growth. This result was compatible with (These results agree with the results of (Abdel-Ghani et al., 2011; Coetzee et al., 1995; Sahlu and Fernandez, 1992; Reis, 1991). However, the local sheep has dropped in wool characterizes performance less than other breeds sheep in the world, this due to the genotype factor which may affect on the capacity of wool growth by many pathways, for example the skin mass and the ability of follicle to use amino acids (Adams et al., 2000).

Table 4: Effect of treatment with a mixture of amino acid at different levels wool characterizes in the Arabi lambs breed (Means \pm S.E.)

\begin{tabular}{llll}
$\begin{array}{l}\text { Trails } \\
\text { Groups }\end{array}$ & $\begin{array}{l}\text { Crude weight } \\
\text { wool }(\mathrm{g})\end{array}$ & $\begin{array}{l}\text { Clean weight } \\
\text { wool }(\mathrm{g})\end{array}$ & $\begin{array}{l}\text { Fiber length } \\
(\mathbf{c m})\end{array}$ \\
\hline Before treatment & & \\
\hline Control & $0.06 \pm 0.88$ & $0.92 \pm 0.02$ & $0.36 \pm 10.30$ \\
\hline T1 & $0.02 \pm 0.96$ & $0.03 \pm 0.82$ & $0.21 \pm 10.41$ \\
\hline T2 & $0.05 \pm 0.90$ & $0.02 \pm 0.80$ & $0.17 \pm 10.22$ \\
\hline After 90 days of treatment & & \\
Control & $0.07 \mathrm{~b} \pm 2.02$ & $0.02 \mathrm{~b} \pm 1.95$ & $0.32 \mathrm{~b} \pm 10.94$ \\
T1 & $0.04 \mathrm{a} \pm 4.25$ & $0.02 \mathrm{a} \pm 3.00$ & $0.21 \mathrm{a} \pm 13.43$ \\
T2 & $0.05 \mathrm{~b} \pm 2.04$ & $0.06 \mathrm{~b} \pm 1.96$ & $0.11 \mathrm{ab} \pm 12.32$
\end{tabular}

Different small letters within column means a significant difference $(\mathrm{P}<0.05)$ between treatment groups.

Table $(5)$ showed a significant $(\mathrm{P}<0.05)$ increased in carcass characterizes such as Slaughter weight, hot carcass weight, Shoulders, legs and fat tail in in lambs treated with $10 \mathrm{~g} /$ head of a mixture of amino acids compared with T2 and control groups, due to the provide amino acids for animals will alter the fermentation process in the paunch resulting a rise in the synthesis of microbial protein and fatty acids production, those alterations caused more improve in the amount of protein available and energy balance which led to a rise in body growth (Kabir, 2009; Khorshidi, 1996). So, when body growth improve absolutely will reflect positively on the carcass characterizes performance. The reason of increase the fat tail act as the amino acids are used as intermediate components in the production of fatty acids, which can be used for acetyl-CoA production and then in synthesis biochemical of fatty acids (Kiounarsi et al., 2008). Our result has agree with the results of Kiounarsi et al. (2008), but do not agree with Obeidat et al. (2008) may be because they used only methionine but not a mixture of amino acids like present study. No significant $(\mathrm{P}<0.05)$ differences were presented in the weights of lion, heart, liver, lungs and kidney between groups. These results were compatible with Obeidat et al. (2008). 
Table 5: Effect of treatment with a mixture of amino acids at different levels on carcass characterizes in the Arabi lambs breed (Means \pm S.E.)

\begin{tabular}{llll}
$\begin{array}{l}\text { Groups/ } \\
\text { characterizes }\end{array}$ & control & T1 & T2 \\
\hline $\begin{array}{l}\text { Initial body } \\
\text { weight }(\mathrm{kg})\end{array}$ & $24.25 \pm 0.38$ & $24.25 \pm 0.41$ & $24.75 \pm 0.35$ \\
$\begin{array}{l}\text { Slaughter } \\
\text { weight }(\mathrm{kg})\end{array}$ & $31.00 \pm 0.46 \mathrm{~b}$ & $35.25 \pm 0.56 \mathrm{a}$ & $32.50 \pm 0.31 \mathrm{~b}$ \\
\hline $\begin{array}{l}\text { hot carcass } \\
\text { weight }(\mathrm{kg})\end{array}$ & $12.40 \pm 0.17 \mathrm{~b}$ & $13.90 \pm 0.18 \mathrm{a}$ & $13.00 \pm 0.13 \mathrm{ab}$ \\
$\begin{array}{l}\text { Shoulders } \\
\text { (kg) }\end{array}$ & $2.22 \pm 0.11 \mathrm{~b}$ & $3.14 \pm 0.12 \mathrm{a}$ & $2.68 \pm 0.10 \mathrm{ab}$ \\
\hline $\begin{array}{l}\text { Legs }(\mathrm{kg}) \\
\text { Ribs }(\mathrm{kg})\end{array}$ & $4.82 \pm 0.07 \mathrm{~b}$ & $6.18 \pm 0.05 \mathrm{a}$ & $5.80 \pm 0.03 \mathrm{ab}$ \\
\hline $\begin{array}{l}\text { Fat tail }(\mathrm{kg}) \\
\text { Lion }(\mathrm{kg})\end{array}$ & $0.337 \pm 0.01 \mathrm{~b}$ & $0.453 \pm 0.01 \mathrm{a}$ & $0.495 \pm 0.01 \mathrm{a}$ \\
\hline $\begin{array}{l}\text { Heart }(\mathrm{kg}) \\
\text { Liver }(\mathrm{kg})\end{array}$ & $0.087 \pm 0.001$ & $0.088 \pm 0.002$ & $0.090 \pm 0.003$ \\
\hline Lungs $(\mathrm{kg})$ & $0.429 \pm 0.011$ & $0.442 \pm 0.012$ & $0.416 \pm 0.015$ \\
\hline Kidney $(\mathrm{kg})$ & $0.126 \pm 0.001$ & $0.136 \pm 0.001$ & $0.134 \pm 0.001$ \\
\hline
\end{tabular}

Different small letters within class means a significant difference $(\mathrm{P}<0.05)$ between treatment groups.

\section{CONCLUSION}

From the data that observed in this study, it can be suggested that the treatment with a mixture of amino acids at a dose $20 \mathrm{~g} /$ head orally improved some biochemical parameters such as albumin, glucose, TSH and thyroid hormone. While, the dose at $10 \mathrm{~g} /$ head improved the wool and carcasses characterizes in the Arabi lambs breed. Therefore, more studies are needed to evaluate the effect of a mixture of amino acids on other trails such as reproductive in female lambs and rams.

\section{CONFLICT OF INTEREST}

There is no conflict of interest.

\section{AUTHORS CONTRIBUTION}

All authors contributed equally.

\section{REFERENCES}

-Abdel-Ghani AA, Solouma GMA, AbdElmoty AKI, Kassab AY, Soliman EB (2011). Productive performance and blood metabolites as affected by protected protein in sheep. Open J. Anim. Sci. 1: 24-32. https://doi.org/10.4236/ ojas.2011.12004

-Adams NR, Liu SM, Briegel JR, Greeff JC (2000). Protein metabolism in skin and muscle of sheep selected for or against staple strength. Aust. J. Agric. Res. 51:541-546. https://doi.org/10.1071/AR99143

-Ana-Maria S, Victor B, Barbara M (2009). New Trends In Classification, Diagnosis And Management Of Thyroid Diseases. The 9th EFCC Continuous Postgraduate Course in Clinical Chemistry Under the Auspices of IFCC. Handbook, Dubrovnik, Pp 1-118.

- Black JL, Reis PJ (1979). Speculation on the control of nutrient between wool growth and other body functions. In: J. L. and P. j. Reis (Ed.) Physiological and Environmental Limitation to Wool Growth. P 269. Univ. of New England, Armidale, Mew South Wales, Australia.

- Coetzee J, de Wet PJ, Burger WJ (1995). Effects of infused methionine, lysine and rumen-protected methionine derivatives on Nitrogen retention and wool growth of Merino wethers S. Afr. J. Anim. Sci. 25: 87-94.

-Edriss MA, Dashab G, Ghareh Aghaji AA, Nilforoosha MA, Movassagh H (2007). A study of some physical attributes of Naeini sheep wool for textile industry. Pakistan J. Biol. Sci. 10:415-420. https://doi.org/10.3923/pjbs.2007.415.420

- Egan AR, Macrae JC (1979). Amino acid catabolism and gluconeogenesis in sheep. Ann. Rech. Vet. 10: 376-378.

- Grodsky GM (1979). Chemistry and function of hormones thyroid, pancreas and gastrointestinal tract, In: Haper, H.A., Rodwell, V.W. and Mayes, P.H. Eds., Review of Physical Chemistry, 7th Edition, Langer Medical Publication, Los Altos, 34: 511-534.

- Haddad SG, Nasr RE, Muwalla MM (2001). Optimum dietary crude protein level for finishing Awassi lambs. Small Rum. Res. 39:41-46. https://doi.org/10.1016/S09214488(00)00172-3

-Holman BWB, Malau-Aduli AEO (2012). A Review of Sheep Wool Quality Traits. Annual Rev. Res. Biol. 2: 1-14.

- Hoover WH, Miller TK (1991). Rumen digestive physiology and microbial ecology. Vet. Clin. North America Food Anim. Pract. 7: 311-325. https://doi.org/10.1016/S07490720(15)30801-X

-Islam CS, Sharif M, Nisa M, Javaid A, Hashmi N, Sarwar M (2009). Supplementation of Ruminally Protected Proteins and Amino Acids: Feed Consumption, Digestion and Performance of Cattle and Sheep. Int. J. Agric. Biol. 11: 477-482.

- Kabir FM, Shahjala SA, Chowdhury JA, Islam MR (2002). Effect of protein supplementation to grazing on growth and reproductive performance in female goats and sheep. Pak. J. Biol. Sci. 5:719-721. https://doi.org/10.3923/ pjbs.2002.719.721

-Khan MJ, Abbas A, Ayaz M, Naeem M, Akhter MS, Soomro MH (2012). Review:Factors affecting wool quality and quantity in sheep. Afr. J. Bio. 11:13761-13766.

-Khorshidi JK (1996). The effect of the different levels on energy and protein on growth rate and the carcass characteristics of Kurdish male lambs. M. Sc. Thesis, Tehran university, Iran.

- Kiounarsi H, Khorshidi KJ, Zahedifar M, Seidavi AR, Mirhosseini SZ, Taherzadeh MR(2008). The effect of dietary and protein level on performance, efficiency and carcass characteristics of Taleshi lambs. Asian J. Anim. Vet. Adv. 3: 307-313. https://doi.org/10.3923/ajava.2008.307.313

-NRC (2010). National Research Council. Nutrients Requirements of sheep. Sixth Revised Edition. National Academy Press. Washington, D.C.

- Obeidat BS, Abdullah AY, Awawdeh MS, 1 Kridli RT, Titi HH, Qudsieh RI (2008). Effect of methionine supplementation 
on performance and carcass characteristics of Awassi ram lambs fed finishing diets. Asian-Aust. J. Anim. Sci. 21: 831 $-837$.

- Reis PJ (1991). Nutritional regulation of wool growth in Merino sheep. In: Wool biology .E d. Hynd, P.I., Australian Wool Corporation P, arkville, Victoria. p. 57.

- Reis PJ, Panaretto BA (2001). Chemical deflecting as a method of harvesting wool from sheep. World Anim. Rev. 30: 36-42 https://doi.org/10.2527/1994.7271899x.

- Reis PJ, Sahlu T (1994). The nutritional control of the growth and properties of mohair and wool fibers: a comparative review. J. Anim. Sci. 72:1899-1907. https://doi.org/10.1071/ BI9630218

- Reis PJ, Schinckel PG (1963). Some effects of sulphurcontaining amino acids on the growth and composition of wool. Aus. J. Bio. Sci. 16: 218-230.

- Sahlu T, Fernandez JM (1992). Effect of intraperitoneal administration on lysine and methionine on mohair yield and quality in Angora goats. J. Anim. Sci. 70: 3188-3193 https://doi.org/10.2527/1992.70103188x.

-SPSS (2013). Statistical Package for the Social Studies, Advanced Statistics, Version 10.0 for Windows, SPSS Inc., Chicago, USA.
- Taherpour N, Salehi M, Mirzaei F (2012). Evaluation certain environment factors on wool characteristics of Arabi sheep breeds. Open J. Anim. Sci. 2:11-14. https://doi.org/10.4236/ ojas.2012.21002

-Thornberry K, Atkins K (1984). Variation in non-wool components of the greasy fleece over the body of Merino sheep. Aust. J. Expt. Agric. 24:62-76. https://doi. org/10.1071/EA9840062

-Velle W, Sjaastad OV, Aulie A, Gronset D, Feigenwinter K, Framstad T (1997). Rumen escape and apparent degradation of amino acids after individual intraruminal administration to cows. J. Dairy Sci. 80: 3325- 3332. https:// doi.org/10.3168/jds.S0022-0302(97)76308-2

-Williams AJ, Winston RJ (1987). A study of the characteristics of wool follicle and fiber in merino sheep genetically different in wool production. Aust. J. Agric. Res. 38: 743-755. https:// doi.org/10.1071/AR9870743

-Yurtman IY, Savas T, Karaagac F, Coskuntuna L (2002). Effect of daily protein intake levels on the oral stereotypic behaviors in emery restricted lambs. Applied Anim. Behav. Sci. 77:7788. https://doi.org/10.1016/S0168-1591(02)00025-4 